\title{
KESAN PERTUKARAN AGAMA IBU BAPA TERHADAP STATUS AGAMA ANAK
}

\author{
Mohamed Azam Mohamed Adil* \\ Rafeah Saidon**
}

\section{Pendahuluan}

Dalam konteks masyarakat berbilang kaum di Malaysia, isu penentuan agama dan hak penjagaan kanak-kanak sering menjadi perbahasan apabila salah satu pihak yang perkahwinannya didaftarkan di bawah Akta Pembaharuan (Perkahwinan dan Perceraian) 1976 (Akta 164) memeluk agama Islam. Pemelukan agama Islam oleh salah seorang pasangan ini menjadi asas kepada pembubaran perkahwinan. Bagi pihak yang beragama Islam, ia akan ditentukan oleh Mahkamah Syariah dan bagi pihak bukan Islam oleh Mahkamah Sivil. Tetapi sehingga pihak yang tidak memeluk Islam memfailkan petisyen perceraiannya di Mahkamah Sivil, perkahwinan itu dianggap kekal. Ini menyebabkan masalah kepada pihak yang memeluk agama Islam untuk memohon penceraian di Mahkamah Syariah. Mahkamah Syariah hanya dapat merungkai perkahwinan tersebut tetapi tidak dapat mengesahkan perceraian itu kerana pihak yang tidak memeluk Islam tidak memfailkan perceraiannya di Mahkamah Sivil.

Hal ini menjadi lebih rumit apabila pihak yang memeluk agama Islam menukar agama anak atau jagaannya yang di bawah umur kepada Islam tanpa pengetahuan dan persetujuan pihak yang bukan Islam. Seterusnya, pihak yang beragama Islam juga menuntut hak penjagaan anak di Mahkamah Syariah.

Justeru itu, satu Rang undang-undang bagi pindaan Akta 164 (RUU 164) telah diusulkan di Dewan Rakyat pada 21 November 2016 untuk menangani isu pertukaran agama kepada Islam oleh salah seorang pasangan yang berkahwin.

RUU 164 ini mencadangkan bahawa hak untuk memfailkan petisyen perceraian haruslah juga diberikan kepada pasangan yang telah menukar agama di bawah seksyen 51(1) Akta 164. Ini kerana sebelum ini, hak di bawah Akta 164 ini hanya diberikan kepada pasangan yang kekal dalam agama asal. Oleh itu, isu timbul apabila pasangan yang kekal pada agama asalnya tidak membuat sebarang petisyen ke Mahkamah Sivil, maka perkahwinan mereka dianggap masih sah di bawah Akta 164.

Apabila perkahwinan mereka masih dikira sah, maka menjadi suatu kesulitan bagi pasangan yang menukar agama untuk menuntut haknya seperti nafkah, hak penjagaan anak dan hak pembahagian aset bersama. 
Kesulitan juga bakal timbul apabila kedua-dua pasangan membuat permohonan kepada dua mahkamah yang berbeza iaitu Mahkamah Sivil dan Mahkamah Syariah. Keadaan menjadi lebih rumit apabila kedua-dua mahkamah mengeluarkan arahan yang berbeza.

Mahkamah Syariah juga tidak dapat mengeluarkan arahan untuk membatalkan perkahwinan sivil di bawah Akta 164 kerana kuasa untuk melakukan sedemikian hanyalah terletak pada Mahkamah Sivil.

Pindaan ini memuatkan pada Klausa 7 di mana satu seksyen baru iaitu seksyen 88A dimasukkan mengenai status agama kepada anak salah seorang ibu bapanya memeluk Islam. Seksyen ini menyatakan bahawa anak tersebut hendaklah kekal dengan agama asal sebelum pertukaran agama berlaku melainkan keduadua ibu bapa bersetuju dengan pertukaran agama anak tersebut serta dengan persetujuannya jika dia sudah berumur 18 tahun.

Cadangan memasukkan seksyen baru ini telah menimbulkan kegelisahan orang Islam kerana anak bawah umur daripada perkahwinan sivil akan kekal sebagai bukan Islam walaupun telah diislamkan oleh salah satu ibu bapa atau penjaga sehingga mencapai umur 18 tahun. Akhirnya, pihak kerajaan telah menarik balik RUU 164 ini pada 6 April 2017.

\section{Kesan Ke Atas Pemelukan Islam Oleh Salah Seorang Daripada Perkahwinan Sivil (Akta 164)}

Secara umumnya, dalam Islam, perkahwinan hendaklah terdiri daripada pasangan beragama Islam kecuali bagi wanita kitabiyyah (Seksyen 10, Enakmen Undangundang Keluarga Islam Selangor 2003).

Apakah kedudukannya sekiranya salah seorang daripada pihak pasangan bukan Islam yang mendaftarkan perkahwinannya di bawah Akta 164 memeluk agama Islam? Seksyen 46(1) Enakmen Undang-undang Keluarga Islam Selangor 2003 dan enakmen di negeri lain memperuntukkan:

"Pemelukan Islam oleh salah seorang pasangan bukan Islam, secara tersendirinya, tidak menyebabkan perkahwinan itu terbubar kecuali ia disahkan oleh Mahkamah Sivil".

Peruntukan ini jelas menunjukkan bahawa Mahkamah Syariah mempunyai kuasa prerogatif dalam membuat pengesahan perceraian ke atas sesuatu pasangan. Masalah yang timbul dalam kes yang melibatkan pemelukan agama Islam oleh salah satu pihak yang perkahwinannya didaftarkan di bawah Akta 164, pengesahan perceraian oleh Mahkamah Syariah tidak diiktiraf oleh Mahkamah Sivil dan ini tidak mempunyai apa-apa kesan terhadap perkahwinan asal. 
Akta 164 memperuntukkan pemelukan Islam sebagai sebab untuk pembubaran perkahwinan. Seksyen 51 Akta 164 memperuntukkan:

“Apabila salah seorang kepada perkahwinan itu memeluk agama Islam, pihak yang satu lagi yang tidak memeluk agama Islam boleh memohon petisyen perceraian.

Dengan syarat bahawa tiada petisyen boleh dibuat di bawah Seksyen ini sebelum tempoh tiga bulan tamat dari tarikh pemelukan tersebut".

Peruntukan dalam Akta 164 ini mengundang beberapa masalah. Ini kerana, peruntukan di atas tidak terpakai ke atas pihak yang beragama Islam. Justeru, Seksyen 51 hanya memberi hak kepada pihak yang bukan beragama Islam sahaja untuk memfailkan petisyen perceraian di Mahkamah. ${ }^{1}$ Ahmad Ibrahim adalah orang pertama yang menulis mengenai keperluan meminda seksyen 51 Akta 164 bagi memberi keadilan kepada pihak yang memeluk agama Islam untuk memfailkan petisyen perceraian di Mahkamah Syariah. ${ }^{2}$ Ini kerana pihak yang beragama Islam tidak boleh memfailkan petisyen perceraian di bawah Seksyen 52 Akta 164 (perceraian melalui persetujuan kedua belah pihak) dan Seksyen 53-54 Akta 164 (keruntuhan rumahtangga yang tidak boleh diselamatkan lagi) meskipun pemelukan agama Islam dianggap sebagai salah satu asas tersebut. Melihat kepada fakta dalam peruntukan Seksyen 51 yang menganggap pemelukan Islam sebagai punca perceraian, dan melihat kepada peruntukan Seksyen 3 Akta 164, adalah mustahil untuk melihat kepada peruntukan lain dalam Akta 164 sebagai asas kepada perceraian kerana ia hanya terpakai kepada pihak yang bukan beragama Islam. ${ }^{3}$ Justeru itu, adalah elok Seksyen 51 Akta 164 ini dipinda bagi memberikan hak kepada salah satu pihak yang memeluk agama Islam untuk memohon petisyen perceraian. ${ }^{4}$

Memandangkan bahawa Akta 164 dan EUKIS 2003 mengiktiraf pemelukan agama sebagai asas kepada perceraian, siapakah yang berhak ke atas penentuan agama dan hak penjagaan kanak-kanak tersebut? Undang-undang manakah yang terpakai dan bidang kuasa mahkamah mana, Mahkamah Sivil atau Mahkamah Syariah?

Pemelukan agama Islam oleh salah satu pihak yang berkahwin di bawah Akta 164 dan kemudiannya berkait dengan pertukaran agama kanak-kanak serta perebutan hak penjagaan kanak-kanak berikutan pertindihan bidang kuasa antara Mahkamah Sivil dan Mahkamah Syariah serta peruntukan yang tidak jelas dalam isu ini telah menimbulkan polemik yang tidak berkesudahan.

Dalam kes Muhammad Ridhuan Abdullan (Pathmanathan a/l Krishnan) lwn Indira Gandhi $(2015)^{5}$ kedua-dua pihak yang beragama Hindu telah berkahwin mengikut Akta 164. Mereka dikurniakan tiga orang anak, Tevi Darsiny (12 
tahun), Karan Dinish (11 tahun) dan Prasana Diksa (11 bulan) tatkala pihak isteri (Indira) memfailkan semakan kehakiman.

Pada 11 Mac 2009, suami (Pathmanathan) memeluk agama Islam dan dikenali sebagai Muhammad Riduan. Berikutan pengislamannya, pada 8 April 2009, Muhammad Riduan telah memperolehi hak jagaan anak melalui arahan interim ex-parte terhadap ketiga-tiga anak tersebut. Kemudian, beliau telah mendapat hak jagaan anak secara tetap melalui arahan Mahkamah Syariah Ipoh pada 29 September 2009.

Semasa suami memeluk Islam, dua orang anak mereka tinggal bersama Indira dan yang bongsu tinggal bersama Muhammad Riduan.

Pada April 2009, pihak isteri menerima beberapa dokumen daripada pihak suami yang menerangkan bahawa ketiga-tiga anak-anaknya telah memeluk agama Islam pada 2 April 2009 dengan bukti Sijil Pemelukan Islam yang dikeluarkan oleh Pengarah Jabatan Agama Islam Perak (JAIP). Terdapat juga dokumen yang menunjukkan bahawa Pendaftar Muallaf telah mendaftarkan ketiga-tiga anak tersebut sebagai orang Islam.

Indira kecewa dan tidak berpuas hati dengan tindakan pihak suami lalu memfailkan permohonan semakan kehakiman di Mahkamah Tinggi Ipoh memohon antara lain supaya Mahkamah membatalkan sijil-sijil pemelukan Islam anak-anaknya kerana bercanggah dengan Seksyen 99, 100 dan 101 Enakmen Pentadbiran Agama Islam Perak 2004 (selepas ini Enakmen 2004). Seterusnya pihak isteri memohon supaya sijil-sijil tersebut diisytihar tidak sah dan terbatal serta tidak mempunyai kesan disebabkan ultra vires kerana tidak selari dengan peruntukan dalam Bab IX dan secara khusus seksyen 106(b) Enakmen 2004; seksyen 5 dan 11 Akta Hak Jagaan Anak-anak 1961; dan Perkara 12(4) dibaca bersama Perkara 8(2) Perlembagaan Persekutuan. Tuntutan tambahan dan secara alternatif, pihak isteri memohon deklarasi bahawa setiap anak tersebut tidak memeluk agama Islam mengikut undang-undang.

Pada 25 Julai 2013, Pesuruhjaya Kehakiman membenarkan permohonan pihak isteri. Ketiga-tiga sijil pemelukan Islam yang dikeluarkan oleh Pengarah JAIP diketepikan dan diisytiharkan batal, tidak sah dan tidak mempunyai apa-apa kesan.

Muhammad Riduan membuat rayuan di Mahkamah Rayuan terhadap keputusan Mahkamah Tinggi Ipoh. Dalam keputusan majoriti 2-1, Mahkamah Rayuan membenarkan Rayuan Muhammad Riduan yang telah mendapat pengesahan agama Islam bagi tiga orang anak-anaknya seperti yang tertera dalam sijil pemelukan Islam yang dikeluarkan oleh Pengarah JAIP.

Dalam membuat keputusan tersebut, Hakim Balia Yusof $\mathrm{Hj}$. Wahi bersama Hakim Badariah Sahamid memutuskan bahawa hanya Mahkamah Syariah yang mempunyai hak bidang kuasa eksklusif untuk memutuskan pertikaian yang berkaitan 
dengan agama seseorang itu dalam isu pemelukan Islam. Ini terutamanya dengan melihat kepada Enakmen 2004 yang mengandungi peruntukan berkaitan proses pemelukan, bidangkuasa Mahkamah Syariah Negeri dan kuasa yang diberikan kepada Pendaftar Muallaf Negeri yang mengeluarkan sijil pemelukan Islam.

Dalam hujah bertentangan, Hakim Hamid Sultan Abu Backer memutuskan bahawa Mahkamah Tinggi Ipoh masih mempunyai kuasa untuk menentukan isu pemelukan kerana peruntukan yang berkaitan pemelukan dalam Enakmen 2004 tidak semestinya terletak di bawah Mahkamah Syariah. Hanya seksyen 50 Enakmen 2004 yang berkaitan dengan Mahkamah Syariah Negeri mempunyai kuasa melebihi apa yang diberikan kepada Mahkamah Tinggi Sivil. Hakim Hamid Sultan seterusnya mengatakan bahawa Enakmen 2004 menghendaki tiga anak tersebut mengucap dua kalimah syahadah di hadapan pegawai agama, tidak seperti apa yang telah berlaku di mana pemelukan Islam oleh anak-anak tersebut hanya dibuat oleh pihak bapa iaitu Muhammad Riduan.

Dalam kes Eeswari Visuvalingam lwn Kerajaan Malaysia, ${ }^{6}$ perayu telah berkahwin dalam bulan November 1950 mengikut kepercayaan agama Hindu. Perkahwinan tersebut telah didaftarkan di bawah undang-undang Sivil pada 15 November 1950. Pada 16 Jun 1978 suami perayu telah memeluk agama Islam. Suami perayu adalah pesara kerajaan. Malangnya, suami perayu meninggal dunia pada 7 January 1985. Perayu mendakwa bahawa beliau berhak ke atas pencen suaminya mengikut seksyen 15 Akta Pencen 1980. Jabatan Pencen menolak permohonan perayu untuk mendapatkan pencen terbitan kerana berlainan agama. Perayu membawa kes ini ke Mahkamah Tinggi dan keputusannya ialah sama dengan Jabatan Pencen. Perayu membawa kes ini ke Mahkamah Agung. Mahkamah Agung memutuskan bahawa perkahwinan perayu dengan suaminya adalah sah mengikut undang-undang sivil semasa kematian suaminya. Justeru, perayu berhak mendapat pencen terbitan. ${ }^{7}$

Dalam kes Pedley lwn Majlis Agama Islam Pulau Pinang, ${ }^{8}$ Hakim Wan Adnan memutuskan bahawa perkahwinan orang bukan Islam tidak secara automatik terungkai dengan salah seorang daripada mereka memeluk Islam. Ia hanya memberi hak kepada pihak yang bukan Islam untuk memfailkan petisyen pembubaran perkahwinan di bawah undang-undang sivil. Semasa memutuskan penghakiman, Hakim Wan Adnan merujuk kepada keputusan Kadi Besar yang mengatakan bahawa perkahwinan tersebut adalah terbubar di bawah undangundang Islam. Walau bagaimanapun, Hakim Wan Adnan memutuskan bahawa keputusan Kadi Besar itu tidak menjejaskan kedudukan plaintif daripada segi undang-undang personal di bawah undang-undang sivil. ${ }^{9}$

Terdapat pihak yang memeluk agama Islam tetapi tidak bertanggung jawab kerana menggunakan seksyen 51 Akta 164 untuk mengelak daripada membayar nafkah. Ini dapat dilihat dalam kes Letchumy lwn Ramadason ${ }^{10}$ di mana plaintif 
yang membuat petisyen telah mendapat perintah perceraian daripada Mahkamah atas alasan responden telah menghilangkan diri. Pesuruhjaya Kehakiman mengarahkan responden membayar RM200 sebulan sebagai bayaran nafkah. Pihak responden seterusnya memohon perintah mengenepikan perintah tersebut atas alasan bahawa dia telah memeluk agama Islam. Tambahan pula, mengikut undang-undang Islam, pihak yang bukan Islam tidak berhak menuntut nafkah kerana tidak turut serta memeluk agama Islam semasa iddah. Mahkamah Tinggi memutuskan bahawa memandangkan seksyen 3 (1) Akta 164 tidak terpakai ke atas pihak yang beragama Islam dan responden telah memeluk agama Islam, Akta 164 tidak terpakai ke atasnya. ${ }^{11}$

Walau bagaimanapun, keputusan yang dibuat dalam kes Letchumy telah diketepikan dalam kes Tan Sung Mooi v Too Miew Kim. ${ }^{12}$ Mahkamah Agung memutuskan bahawa kedua-dua pihak adalah bukan Islam semasa perkahwinan dan perkahwinan itu dilangsungkan mengikut kepercayaan agama bukan Islam. Memandangkan bahawa petisyen pembubaran perkahwinan itu didaftarkan dibawah seksyen 76 dan seksyen 77 Akta 164 yang melibatkan pihak bukan Islam dan secara langsung berkaitan dengan pembubaran perkahwinan, sudah tentulah Mahkamah sivil yang merupakan mahkamah yang kompeten untuk mendengar dan menentukan tuntutan sampingan lain. Fakta bahawa responden telah memeluk agama Islam setelah pembubaran perkahwinan dibuat adalah tidak penting kerana ia berlaku sebelum tuntutan sampingan lain itu didengar di mahkamah.

Mahkamah Agung juga memutuskan bahawa walaupun Perkara 121 (1A) mengeluarkan bidang kuasa Mahkamah Tinggi daripada mendengar perkara yang termasuk dalam bidang kuasa Mahkamah Syariah, tetapi Mahkamah Syariah tidak mempunyai bidang kuasa terhadap orang bukan Islam. Justeru itu, Perkara 121 (1A) Perlembagaan Persekutuan tidak memberi kesan ke atas bidang kuasa Mahkamah Tinggi untuk mendengar permohonan di bawah seksyen 76 dan seksyen 77 Akta $164 .^{13}$

\section{Apakah Agama Kanak-Kanak Mengikut Agama Ibu Atau Bapa Yang Memeluk Islam?}

Dalam undang-undang Islam, para fuqaha telah berijmak bahawa apabila kedua ibu bapa memeluk agama Islam, secara automatik agama kanak-kanak bawah umur juga adalah Islam.

Permasalahan yang timbul apabila hanya satu pihak yang memeluk agama Islam dan pihak yang satu lagi kekal sebagai bukan Islam telah membawa kepada perbincangan yang menarik dalam perbahasan fiqh. Para fuqaha telah berijmak bahawa agama seseorang kanak-kanak adalah mengikut ayahnya yang 
beragama Islam. Ini termasuk apabila bapanya memeluk agama Islam. Walau pun begitu, pandangan majoriti yang terdiri daripada mazhab Hanafi, Syafi'i dan Hanbali berpendapat agama bagi kanak-kanak adalah mengikut pihak yang memeluk Islam tanpa mengira ibu atau bapa. Walau bagaimanapun, mengikut mazhab Maliki, agama seseorang kanak-kanak adalah mengikut bapanya sekira bapa yang memeluk agama Islam. Ini kerana identiti dan keturunan nasab adalah melalui bapa. ${ }^{14}$

\section{Apakah Kanak-kanak Boleh Memeluk Agama Islam?}

Para fuqaha juga tidak sepakat sama ada seseorang kanak-kanak boleh memeluk sesuatu agama termasuk agama Islam. Ramai fuqaha berpandangan bahawa kanak-kanak boleh memeluk agama Islam berdasarkan fakta terdapat para sahabat Nabi Muhammad SAW yang memeluk agama Islam semasa usia kanakkanak. Antara mereka ialah Ali bin Abi Talib, Zubayr bin al-Awwam, Abdullah ibn Umar dan Asmak binti Abu Bakar. ${ }^{15}$

Imam Abu Hanifah dan anak muridnya, Muhammad Hassan al-Syaibani berpendapat bahawa pemelukan Islam atau murtad oleh kanak-kanak mumayyiz adalah sah. Bagaimanapun, Abu Yusuf berpandangan, ianya hanya sah dalam pemelukan Islam tetapi tidak sah dalam kes murtad. Zufayr Hudhayl, seorang lagi anak murid Imam Abu Hanifah berpandangan bahawa seseorang kanakkanak tidak boleh memeluk Islam atau keluar Islam kerana belum cukup umur baligh. Ianya hanya sah apabila kanak-kanak itu mencapai umur baligh. Hujah Zufayr ialah kanak-kanak bawah umur tidak mempunyai kelayakan untuk memilih agama. ${ }^{16}$

Dalam satu Hadis popular "Setiap anak dilahirkan dalam keadaan fitrah. Ibu bapalah yang akan menentukan sama ada dia seorang Yahudi atau Kristian sehingga dia berkemampuan untuk menerima atau menolaknya". ${ }^{17}$ Justeru itu, kanakkanak tidak boleh menentukan agama. Ini ditambah pula bahawa kanak-kanak itu fitrah (bersih daripada dosa) dan tidak ditaklifkan (dipertanggungjawabkan) tanpa mengira amalan sama ada dia seorang Islam atau tidak. Hadis ini menyebut ibu bapa.

Secara umum agama seseorang kanak-kanak adalah mengikut agama ibu bapanya yang Islam. Tetapi keadaan berbeza sekiranya berlaku pertikaian antara ibu atau bapa dalam menentukan agama kanak-kanak itu. Oleh yang demikian, cara yang terbaik dalam menangani kemelut ini ialah dengan menyerahkan kepada mahkamah/tribunal untuk membuat satu ketetapan yang menjurus kepada keadilan dan kebajikan kanak-kanak tersebut. 


\section{Penentuan Agama Kanak-kanak Bawah Umur}

Undang-undang di Malaysia telah mewujudkan peruntukan undang-undang bagi pertukaran agama seseorang kepada Islam. Peruntukan sedemikian didapati pada enakmen di peringkat negeri iaitu dalam undang-undang pentadbiran Islam negeri. Undang-undang tersebut pada mulanya merupakan sebuah peruntukan yang ringkas. Enakmen yang paling awal hanya menyatakan bahawa Majlis Agama Islam hendaklah mendaftarkan setiap individu yang menukar agamanya. Ini bermakna seseorang tidak boleh menukar agamanya melainkan ianya dilakukan selaras dengan peruntukan enakmen terbabit, iaitu seseorang individu yang yang belum mencapai usia akil baligh tidak dibenarkan sama sekali untuk menukar agamanya, dan setiap pertukaran agama perlu didaftarkan di bawah Majlis Agama Islam. ${ }^{18}$

Meskipun begitu, penentuan agama kanak-kanak bagi salah satu pihak yang memeluk agama Islam juga masih menjadi persoalan besar dan tidak berkesudahan kerana ia melibatkan satu pihak yang memeluk agama Islam dan satu lagi bukan Islam. Ia menjadi polemik apabila kabinet pada 23 April 2009, antara lain memutuskan bahawa pengislaman kanak-kanak bawah umur 18 tahun hendaklah mendapat persetujuan kedua ibu bapa kanak-kanak tersebut. Sekiranya persetujuan tidak tercapai antara salah satu pihak yang masih enggan memeluk agama Islam dan satu pihak yang memeluk agama Islam, agama bagi kanak-kanak tersebut adalah mengikut pihak yang bukan Islam kerana asal perkahwinan adalah mengikut bukan Islam. ${ }^{19}$

Ia sekali lagi menjadi polemik apabila Rang Undang-undang Pentadbiran Islam Wilayah Persekutuan 2013 dibentangkan untuk bacaan kali pertama di Dewan Rakyat. Peruntukan yang menjadi isu di sini ialah dalam Seksyen 107 Rang Undang-undang Pentadbiran Islam Wilayah Persekutuan 2013 mengenai keupayaan untuk memeluk agama Islam. Kanak-kanak yang bukan beragama Islam boleh memeluk agama Islam sekiranya dia waras dan sudah mencapai umur 18 tahun. Bagi kanak-kanak berumur kurang dari 18 tahun, ia perlu mendapat izin ibu atau bapa atau penjaganya. ${ }^{20}$

Isu ini sekali lagi kecoh dan mendapat bantahan apabila kerajaan membawa usul pindaan ke atas Akta 164 pada 21 November 2016 di Dewan Rakyat bagi memasukkan peruntukan baru Seksyen 88A (1) yang memperuntukkan:

"Apabila pihak kepada perkahwinan memeluk agama Islam, agama kanak-kanak dari perkahwinan itu akan kekal mengikut agama pihakpihak yang berkahwin sebelum pemelukan Islam, kecuali apabila kedua-dua pihak kepada perkahwinan itu bersetuju terhadap penukaran agama kanak-kanak kepada Islam, tetapi ia tertakluk kepada hasrat kanak-kanak tersebut apabila ia mencapai umur 18 tahun." 
Manakala seksyen 88A (2) memperuntukkan:

"Apabila pihak-pihak kepada perkahwinan itu menganut agama lain sebelum pemelukan salah satu pihak kepada Islam, kanak-kanak kepada perkahwinan itu haruslah bebas kekal dalam agama salah satu dari pihak agama asal sebelum pemelukan agama Islam tersebut."

Dalam konteks di Malaysia, Perkara 12 (4) Perlembagaan Persekutuan memperuntukkan "Bagi maksud Fasal (3), agama bagi seseorang yang berumur kurang daripada lapan belas tahun adalah ditetapkan oleh ibu bapa atau penjaganya". Melihat kepada versi dalam Bahasa Inggeris, ia menyebut perkataan 'parent' yang membawa maksud ibu atau bapa. Sekiranya perkataan 'parents' ditulis dengan jelas, ia membawa maksud ibu bapa.

Para ahli perundangan dan akademik membuat tafsiran yang berbeza mengenai perkataan 'parent' dalam Perkara 12(4) Perlembagaan Persekutuan. Bagi yang menyokong ia membawa maksud kedua ibu bapa, mereka merujuk kepada Perkara 160 Perlembagaan Persekutuan dalam tafsiran 'his' (dia lelaki) meliputi 'her' (dia perempuan). Begitu juga perkataan 'parent' hendaklah juga difahami secara jamak iaitu 'parents'. Interpretasi ini didokong oleh Shaad Saleem Faruqi, Majlis Peguam Malaysia dan pertubuhan-pertubuhan NGO termasuk juga partiparti komponen BN seperti MCA, MIC dan Gerakan. ${ }^{21}$

Persatuan Peguam Muslim Malaysia (PPMM) dan Persatuan Peguam Syarie Malaysia (PGSM) berhujah bahawa penentuan agama kanak-kanak secara unilateral adalah selaras dengan keputusan dalam kes Susie Teoh ${ }^{22}$ di mana Mahkamah Persekutuan memutuskan bahawa penentuan agama seorang kanak-kanak bawah 18 tahun adalah dengan kebenaran ibu atau bapa atau penjaganya. ${ }^{23}$

Ini disusuli dengan kes Subashini a/p Rajasingam lwn Saravanan a/l Thangthoray \& Anor ${ }^{24}$ di mana Mahkamah Persekutuan memberi takrifan 'parent' sebagai salah seorang daripada ibu atau bapa. Dengan itu, pengislaman anak oleh bapa yang memeluk Islam adalah sah. Ini tidak dipersetjui oleh Majlis Peguam kerana pada kaca mata mereka hujah yang mengatakan hanya cukup salah seorang ibu atau bapa dalam memberi keizinan agama seseorang kanak-kanak berlawanan dengan Perkara 12 (4) Perlembagaan Persekutuan dan keputusan Mahkamah Persekutuan tersebut adalah khilaf. Ini kerana pada pandangan mereka, Mahkamah Persekutuan tidak mengambil kira takrifan dalam Perkara 160 Perlembagaan Persekutuan.

Perlu dimaklumkan bahawa buat masa sekarang terdapat negeri yang memperuntukkan keperluan keizinan ibu dan bapa, dan terdapat juga negeri yang hanya memperuntukkan keperluan keizinan ibu atau bapa dalam pengislaman kanak-kanak bawah 18 tahun. 
Sebagai contoh di negeri Selangor, Seksyen 117 Enakmen Undang-undang Pentadbiran Agama Islam Selangor 2003 mensyaratkan keizinan ibu dan bapa atau penjaga dalam pemelukan Islam kanak-kanak bawah 18 tahun.

Manakala bagi Wilayah Persekutuan, Kedah dan Perak tidak mensyaratkan persetujuan ibu dan bapa atau penjaga. Cukup dengan persetujuan salah satu dari ibu atau bapa atau penjaga dalam perkara ini. Ini dapat dilihat dalam Seksyen 95 Akta Pentadbiran Undang-Undang Islam Wilayah-Wilayah Persekutuan 1993, Seksyen 80 Enakmen Pentadbiran Undang-Undang Islam Kedah 2008, dan Seksyen 106 Enakmen Pentadbiran Agama Islam Perak 2004.

Meskipun begitu, ketetapan yang dibuat oleh Muzakarah Jawatankuasa Fatwa Majlis Kebangsaan Bagi Hal Ehwal Ugama Islam Malaysia kali ke 87 pada 25 Jun 2009 memutuskan bahawa apabila salah seorang ibu atau bapa memeluk Islam, agama anak di bawah umur adalah mengikut Islam dan hak penjagaan anak tersebut hendaklah diletakkan di bawah ibu atau bapa yang beragama Islam. Apa yang menarik perhatian ialah Muzakarah Jawatankuasa Fatwa tersebut memutuskan bahawa Perkara 12(4) Perlembagaan Persekutuan yang memperuntukkan bahawa agama seseorang di bawah 18 tahun adalah mengikut ketetapan oleh ibu atau bapa tidak perlu dipinda. Keputusan fatwa ini telah diikuti oleh Sabah, Sarawak dan Pahang. Malangnya kesemua fatwa tersebut tidak diwartakan. ${ }^{25}$

Mengambil kira bantahan dan tentangan daripada para mufti, ulama dan pertubuhan Islam, kerajaan telah menangguhkan bacaan kedua terhadap pindaan Akta 164 pada sidang Dewan Rakyat pada 6 April 2017. Penangguhan ini adalah bagi membincangkan semula isu pertukaran agama kanak-kanak secara unilateral. Ini bagi mendapat maklum balas daripada pakar agama, badan bukan kerajaan dan ahli politik. ${ }^{26}$

\section{Hak Penjagaan Anak Menurut Undang-undang Islam dan Undang- undang Sivil}

Seksyen 51 Akta 164 menganggap pemelukan Islam sebagai punca perceraian. Justeru itu, adalah mustahil untuk melihat kepada peruntukan lain dalam Akta 164 sebagai asas kepada perceraian kerana ia hanya terpakai kepada pihak yang bukan beragama Islam. ${ }^{27}$

Memandangkan Akta 164 dan EUKIS 2003 mengiktiraf pemelukan agama Islam sebagai asas kepada perceraian, siapakah yang berhak ke atas hak penjagaan kanak-kanak tersebut? Undang-undang manakah yang terpakai dan bidang kuasa mahkamah mana, Mahkamah Sivil atau Mahkamah Syariah? Apakah hak penjagaan anak diserahkan kepada pihak yang memeluk Islam kerana faktor agama? 
Dalam konteks undang-undang Islam, para fuqaha berpandangan bahawa apabila sesebuah perkahwinan itu terungkai, hak milik penjagaan kanak-kanak adalah diberi kepada ibunya. Secara fitrah, ini adalah hak mutlak ibu dan kelayakan itu melihat kepada "keperluan" anak kepada ibu berbanding kepada bapa. Tambahan pula, ibulah yang lebih mempunyai perasaan belas kasihan dan bertimbang rasa berbanding bapa kerana secara fitrahnya hubungan anak adalah lebih rapat dengan ibunya kerana ibu yang menyusukan anak, mempunyai sifat lebih sabar, mempunyai pengetahuan yang lebih tentang keperluan anak daripada segi pendidikan dan membesarkannya. Atas alasan-alasan di atas, ibu yang merupakan seorang yang diberi keutamaan dalam penjagaan kanak-kanak. ${ }^{28}$

Para fuqaha menyimpulkan bahawa hak penjaga kanak-kanak bukan hanya melihat kepada keperluan harian dan menjaganya sahaja, malah mereka hendaklah bertanggungjawab dalam memutuskan semua perkara yang kanak-kanak itu tidak dapat membuat keputusan untuk dirinya yang melibatkan pembangunan dirinya dan pendidikan untuknya. ${ }^{29}$

Prinsip ini telah dimasukkan ke dalam undang-undang keluarga Islam di Malaysia. Sebagai contohnya, seksyen 82(1) Undang-undang Keluarga Islam Selangor 2003 memperuntukkan:

"Tertakluk kepada seksyen 83, ibu seharusnya menjadi orang yang lebih berhak dari orang lain dalam hak penjagaan kanak-kanak kecil semasa dan selepas perkahwinan".

Manakala seksyen 82(2) menyenaraikan mereka yang berhak ke atas penjagaan kanak-kanak mengikut keutamaan, sekiranya ibu hilang kelayakan hak penjagaan kanak-kanak mengikut hukum Syarak. Walaupun begitu, di hujung seksyen berkenaan, ia memperuntukkan sesiapa yang berhak ke atas penjagaan kanak-kanak itu tidak sama sekali menyebabkan kebajikan kanak-kanak tersebut terabai. ${ }^{30}$

Bagi memastikan kepentingan kanak-kanak terpelihara, Mahkamah Syariah juga diberi kuasa untuk menentukan siapa yang berhak ke atas penjagaan kanak-kanak. Dalam hal ini, Mahkamah Syariah, dari semasa ke semasa, boleh memutuskan hak penjagaan kanak-kanak diberi kepada mereka yang tersenarai dalam peruntukan seksyen 82(2) atau memberi hak penjagaan tersebut kepada sesiapa dan pertubuhan yang pada pandangan Mahkamah dapat menjaga kebajikan kanak-kanak tersebut. ${ }^{31}$

Bagi orang bukan Islam, mereka tertakluk kepada Akta Penjagaan Kanakkanak 1961 dan Akta 164. Sebagai contohnya, seksyen 3 Akta Penjagaan Kanak-kanak 1961 memperuntukkan penjaga kepada kanak-kanak hendaklah semestinya mempunyai hak penjagaan yang bertanggungjawab dalam bantuan, kesihatan dan pendidikan kanak-kanak tersebut. 
Di bawah seksyen 88(1) Akta 164 memperuntukkan bahawa mahkamah pada bila-bila masa boleh mengarahkan hak penjagaan seseorang kanak-kanak diletakkan kepada bapa atau ibunya atau saudara maranya atau pertubuhan atau seseorang yang layak. Seksyen 88(2) Akta 164 mensyaratkan, dalam menentukan siapa yang berhak menjaga kanak-kanak ialah dengan melihat kebajikannya.

Dari sini dapat dikatakan, kedua-dua undang-undang Islam dan Sivil meletakkan syarat kebajikan kanak-kanak merupakan kriteria utama dalam penentuan hak penjagaan kanak-kanak.

\section{Hak Penjagaan Kanak-kanak Ke Atas Salah Satu Pasangan Yang Memeluk Islam}

Dalam persoalan pemelukan Islam, isu yang timbul ialah siapakah yang berhak ke atas penjagaan kanak-kanak apabila salah seorang pasangan bukan Islam memeluk agama Islam. Para fuqaha berbeza pendapat sama ada pihak yang diberi hak penjagaan kanak-kanak hendaklah menganut agama Islam atau sebaliknya. Tidak terdapat dalil yang jelas kecuali satu hadith yang diriwayatkan oleh Abdul Hamid bin Jaafar yang meriwayatkan bahawa Ibn Sinan telah memeluk agama Islam tetapi isterinya enggan mengikut jejak langkahnya. Isterinya pergi berjumpa Rasulullah SAW. Baginda bersabda:

"Anak perempuan aku, dia telah makan". Rafi berkata: "Anak perempuan aku". Rasulullah SAW berkata kepada beliau: "Duduk di sebelah". Dan baginda berkata kepada mereka: "Panggil anak perempuan itu". Kanak-kanak perempuan itu cenderung kepada ibunya". Rasulullah SAW berkata: "Ya Allah. Pandulah anak perempuan". Anak perempuan itu kemudian cenderung kepada bapanya dan bapanya mengambilnya". ${ }^{22}$

Hadith di atas tidak mengatakan bahawa pihak yang tidak memeluk Islam tidak berhak terhadap hak penjagaan kanak-kanak kerana tidak terdapat arahan sedemikian oleh Rasulullah SAW. Hadith di atas menunjukkan bahawa Rasulullah SAW lebih cenderung bahawa anak itu tinggal bersama dengan bapanya yang masuk Islam bimbang anaknya dapat dipengaruhi oleh emaknya yang bukan Islam dalam aspek akidah.

Menurut mazhab Syafi'e dan Hanbali, penjaga kanak-kanak hendaklah beragama Islam. Sekiranya tidak, gugurlah haknya sebagai penjaga. ${ }^{33}$ Menurut Sayid Sabiq, pandangan ini merujuk kepada ayat 141 Surah al-Nisa':

"Allah tidak akan memberi kejayaan kepada orang kafir terhadap orang yang beriman". 
Hujah yang diberikan ialah, sekiranya kanak-kanak itu diberikan kepada penjaga bukan Islam, adalah dibimbangi ia akan mempengaruhi kepercayaan kanak-kanak itu dan tidak membesarkannya mengikut ajaran Islam. ${ }^{34}$ Hal ini ditekankan dalam Undang-undang Keluarga Islam di Malaysia. Sebagai contohnya, Seksyen 83 Undang-undang Keluarga Islam Selangor 2003 mensyaratkan hanya pihak yang beragama Islam sahaja yang berhak menjadi penjaga kanak-kanak tersebut. Tambahan pula Seksyen 84 Undang-undang Keluarga Islam Selangor 2003 memperuntukkan bahawa hak penjagaan kanakkanak itu akan hilang sekiranya penjaganya murtad.

Walau bagaimanapun, mengikut mazhab Hanafi dan Maliki, syarat beragama Islam bukan menjadi kriteria untuk mendapat hak penjagaan kanak-kanak. Pihak yang tidak memeluk agama Islam boleh mendapat hak penjagaan anak dengan syarat yang ketat di mana kanak-kanak tidak dipengaruhi agama lain seperti membawanya ke gereja, mengajar ajaran bukan Islam atau menyuruh kanakkanak tersebut memakan babi dan minum minuman keras. ${ }^{35}$

Terdapat sesetengah Negara Islam yang membenarkan ibu atau bapa yang bukan Islam menjadi penjaga kepada kanak-kanak Islam. Ini dapat dilihat dalam Seksyen 162 Undang-undang Status Personal Algeria (Algeria Personal Status Law) yang memberi hak penjagaan kanak-kanak kepada ibu yang bukan beragama Islam dengan syarat ia hendaklah membesarkan anaknya mengikut Islam. Ini juga dapat dilihat dalam Seksyen 192 Undang-undang Personal Kuwait (Kuwait Personal Status Law) yang memperuntukkan hak penjagaan kanakkanak boleh diberikan kepada ibu atau bapa yang bukan Islam sehingga kanakkanak itu memahami agama atau sehingga kanak-kanak itu membiasakan diri dengan agama selain Islam meskipun ia tidak memahami agama tersebut. Tetapi kanak-kanak itu hanya boleh tinggal bersama ibu atau bapanya yang bukan beragama Islam sebelum mencapai umur 5 tahun. Kedua-dua undang-undang di Tunisia (Seksyen 59) dan Maghribi (Seksyen 108) mempunyai persamaan dalam menetapkan bahawa ibu atau bapa yang bukan Islam akan hilang kelayakan menjadi penjaga kanak-kanak itu sekiranya melebihi umur 5 tahun kecuali dipercayai ibu atau bapanya tidak membesarkannya secara bukan Islam. ${ }^{36}$

Persoalannya, pandangan mana yang sesuai untuk diterima pakai di Malaysia? Terdapat dua pandangan dalam hal ini. Bagi sesetengah penulis dan pengkaji, melihat kepada Malaysia yang mempunyai masyarakat yang majmuk, pandangan daripada Mazhab Maliki dan Hanafi boleh dipertimbangkan untuk menjamin hubungan harmoni antara ibu dan bapa. ${ }^{37}$ Mengikut pandangan ini, agama ibu atau bapa bukan satu-satunya faktor penentuan hak penjagaan kanakkanak. Justeru itu, sekiranya salah satu pihak memeluk agama Islam, kesemua faktor hendaklah diambil pertimbangan dan mahkamah dalam menentukan siapa yang berhak menjaga kanak-kanak akan melihat kepada kebajikan kanak-kanak 
tersebut. Adalah menjadi tanggung jawab pihak yang tidak memeluk agama Islam menunjukkan imej yang baik mengikut Islam supaya dapat menarik kanakkanak tersebut kepada agama Islam. ${ }^{38}$

Pandangan kedua yang terdiri daripada pandangan mazhab Syafi'e dan Hanbali mensyaratkan ibu atau bapa yang memeluk Islam mempunyai hak penjagaan kanak-kanak. Pandangan ini nampaknya lebih kuat dan lebih memberi manfaat kepada anak tersebut. Memberi hak penjagaan kanak-kanak kepada ibu atau bapa yang tidak memeluk agama Islam hendaklah dielakkan atas justifikasi kebajikan kanak-kanak tersebut. Ini kerana, kanak-kanak dalam peringkat usia yang sangat muda mudah terpengaruh dengan keadaan sekeliling dan ajaran agama penjaga yang bukan Islam. Sepatutnya, kanak-kanak itu didedahkan dan disesuaikan dengan ajaran agama Islam supaya dia menjadi seorang Islam sejati apabila dewasa nanti. Memberi hak penjagaan kanak-kanak kepada penjaga bukan Islam untuk tempoh tertentu seperti yang diamalkan di sesetengah negara Islam adalah tidak digalakkan memandangkan kanak-kanak itu akan lebih rapat dengannya dan mengambil balik hak tersebut dari penjaganya akan mencetus emosi dan psikologinya. ${ }^{39}$ Justeru itu, untuk mengelakkan kemungkinan berlakunya konflik, adalah dicadangkan Mahkamah memberi kepada penjaga bukan Islam hak penjagaan kanak-kanak pada kedudukan yang kecil (a narrower custody order) dengan hanya memberinya peluang menjaga (memelihara) kanak-kanak tersebut (bukan hak hadhanah). Oleh itu, pihak yang memeluk Islam mempunyai hak secara langsung dalam membesarkan anaknya mengikut Islam. ${ }^{40}$

Mahkamah Sivil sekarang nampaknya mengambil pendekatan memberi hak penjagaan bersama kepada kedua ibu bapa walaupun salah satunya bukan beragama Islam. Pendekatan ini dapat dilihat dalam kes Sharmala a/p Sathiyaseelan lwn Dr. Jeyaganesh a/l C Mogarajah. Mereka berdua berkahwin pada 5 November 1998 mengikut adat resam agama Hindu dan perkahwinan mereka didaftarkan di bawah Akta 1976. Empat tahun kemudian, suami (Dr. Jeyaganesh) memeluk agama Islam dan seterusnya juga menukar agama anakanaknya. Sharmala memohon kepada Mahkamah Tinggi Sivil hak penjagaan anak-anak tersebut.

Dalam penghakimannya, Hakim Faiza Thamby Chik telah memberi hak bersama penjagaan anak-anak itu kepada kedua ibu bapa tetapi emak mempunyai hak menjaga dan mengawal anak-anaknya yang meliputi penjagaan seharian dan bertanggungjawab menjaga mereka. Hakim Faiza mengatakan bahawa hak penjagaan anak-anak itu diberi kepada kedua ibu bapa agar mereka bersetuju terhadap isu-isu berkenaan anak-anak seperti pendidikan, pilihan terhadap agama dan harta. Ini mengambil kira Seksyen 5 Akta Penjagaan Kanak-kanak 1961. Meskipun begitu, hakim berkenaan meletakkan kaveat bahawa anak-anak itu adalah seorang muallaf dan hak bersama yang diberi kepada Sharmala (ibu) akan 
hilang sekiranya terdapat alasan yang munasabah yang mempercayai bahawa si ibu akan mempengaruhi agama anak-anaknya atau memberi mereka makan babi dan sebagainya.

Melihat kepada fakta penghakiman kes di atas, dapat dikatakan bahawa penghakiman ini berlandaskan undang-undang Islam tetapi malangnya Hakim Faiza tidak mencadangkan atau mengesyorkan garis panduan bagaimana untuk memastikan ibu yang bukan Islam mematuhi larangan yang diperintahkan oleh Mahkamah. Adalah juga dapat dipertikaikan kaveat yang dikeluarkan kerana ia seolah-olah bercanggah dengan alasan pemberian hak bersama penjagaan anak-anak kepada kedua ibu bapa yang membawa maksud kedua-dua mereka hendaklah bersetuju dengan keputusan yang melibatkan kedua kanak-kanak mereka termasuk cara pendidikan, pilihan agama dan sebagainya. Keputusan ini tidak konsisten dengan keputusan kes Chang $\mathrm{Ah} \mathrm{Mee}^{42}$ yang menyaksikan bahawa emak mempunyai hak penjagaan kanak-kanak walaupun bapanya telah memeluk agama Islam. Tambahan pula, bapa tidak berhak memaksa anak itu ke sekolah agama dengan alasan terdapat ayat dalam al-Quran yang menyebut tidak ada paksaan dalam beragama. ${ }^{43}$

Dalam kes Subashini a/p Rajasingam lwn Saravanan a/l Thangthoray \& Anor ${ }^{44}$ pihak suami telah menukar agamanya kepada Islam. Beliau telah memfailkan prosiding di Mahkamah Syariah untuk membatalkan perkahwinan asalnya dan juga memohon hak penjagaan ke atas anak lelakinya yang turut bertukar agama menganuti Islam. Pihak isteri juga telah memfailkan petisyen bagi membatalkan perkawinan mereka dengan merujuk kepada seksyen 51 Akta 164.

Mahkamah Persekutuan memutuskan bahawa Mahkamah Sivil tidak dibenarkan untuk memutuskan sesuatu yang bercanggah dengan perintah yang dikeluarkan oleh Mahkamah Syariah secara sah serta melalui bidang kuasanya yang sah. Pihak isteri yang telah mendapat perintah mahkamah bagi mengekalkan prosiding pihak suami mengenai pertukaran agama anak lelaki sulung mereka di Mahkamah Tinggi Syariah.

Bagi mengelakkan berlakunya ketidakadilan ke atas pihak isteri yang tidak bertukar agama tersebut dan ke atas anaknya, perkahwinan orang bukan Islam tidak dikira terbatal hanya kerana berlakunya pertukaran agama oleh salah seorang daripada pihak pasangan. Pihak suami boleh menjadi responden bagi prosiding perceraian di Mahkamah Tinggi Sivil. Walau bagaimanapun, pihak isteri yang merupakan orang bukan Islam, tidak mempunyai kedudukan di sisi Mahkamah Syariah yang menghadkan bidang kuasanya hanya ke atas orang Islam sahaja.

Mahkamah memutuskan bahawa pihak suami atau isteri mempunyai hak untuk menukarkan agama anak tersebut kepada Islam dan penukaran agama bagi anak lelaki sulung berkenaan yang dijalankan di bawah Enakmen Selangor tidak bertentangan dengan Perkara 12 (4), Perlembagaan Persekutuan. 
Dalam kes Viran a/l Nagupan lwn Deepa a/p Subramaniam ${ }^{45}$ kedua-dua pihak adalah pasangan Hindu yang telah berkahwin mengikut undang-undang sivil. Viran kemudiannya memeluk Islam dan mengguna pakai nama Izwan Abdullah dan mengislamkan dua anaknya Sharmila (Nurul Nabila) dan Mithran (Nabil) tanpa pengetahuan ibunya pada bulan April 2013. Izwan memohon kepada Mahkamah Syariah hak penjagaan dua anaknya tersebut. Mahkamah Syariah telah membuat keputusan untuk menyerahkan hak penjagaan dua anak tersebut kepada Izwan.

Deepa kemudiannya memohon kepada Mahkamah Tinggi Sivil Seremban memohon hak penjagaan dua anaknya daripada suaminya. Pada 7 April 2014, Mahkamah Tinggi Sivil memutuskan supaya kedua-dua anak tersebut diserahkan hak penjagaan kepada ibunya yang bukan beragama Islam. Hakim Zabariah Mohd dalam masa yang sama turut mengesahkan permohonan S. Deepa untuk membatalkan ikatan perkahwinan dengan bekas suaminya yang telah memeluk Islam pada tahun 2011. Mahkamah tersebut juga turut memberi hak untuk melawat anak-anak mereka secara berkala kepada bapa berkenaan. Izwan telah membawa kes ini ke Mahkamah Rayuan.

Selang beberapa hari, bapa kanak-kanak tersebut, Izwan telah 'menculik' dua anaknya daripada pangkuan ibunya. Pihak bapa memberi alasan bahawa beliau mempunyai hak penjagaan dua anak tersebut kerana dia telah mendapat hak penjagaan tersebut daripada Mahkamah Syariah terlebih dahulu.

Izwan membawa kes tersebut ke Mahkamah Rayuan menuntut hak penjagaan dua orang anak yang telah diislamkan olehnya. Mahkamah Rayuan memutuskan bahawa ia mempunyai bidang kuasa mendengar kes pertikaian yang melibatkan dua pihak yang berlainan agama di mana perkahwinan asalnya di bawah undangundang sivil. Mahkamah Rayuan seterusnya memutuskan bahawa kedua-dua anak Izwan dan Deepa diserahkan kepada Deepa mengambil kira kebajikan mereka. Tidak berpuas hati dengan keputusan ini, Izwan memfailkan rayuan di Mahkamah Persekutuan menuntut hak penjagaan kedua-dua anaknya yang beragama Islam.

Mahkamah Persekutuan memutuskan untuk mengekalkan keputusan Mahkamah Rayuan bahawa platform yang sepatutnya mendengar pertikaian ini ialah Mahkamah Sivil walaupun salah satu pihak yang terlibat adalah orang Islam. Mahkamah Persekutuan memutuskan bahawa Mahkamah Sivil mempunyai bidang kuasa dalam pembubaran perkahwinan dan penentuan hak penjagaan kanak-kanak. Ini kerana, kedua-dua pasangan yang terlibat mendaftar perkahwinan di bawah Akta 164 dan segala isu yang berkaitan selepas itu hendaklah diselesaikan di Mahkamah Sivil. Menurut Mahkamah Persekutuan lagi, Mahkamah Syariah tidak mempunyai bidang kuasa walaupun ke atas pihak yang memeluk Islam. 
Apa yang menarik dalam kes ini ialah Mahkamah Persekutuan sebelum membuat keputusan siapa yang lebih berhak mendapat hak penjagaan kanakkanak telah memanggil kedua-dua anak Izwan dan Deepa, Nurul Nabila (11 tahun) dan Nabil (8 tahun). Dalam keputusan yang "adil" ini, anak lelaki diserahkan hak penjagaan kepada si bapa dan anak perempuan kepada si ibu. Mahkamah Persekutuan seterusnya memutuskan bahawa anak lelaki tersebut masih boleh berhubungan dengan ibunya melalui telefon dan anak perempuan juga boleh berhubungan dengan bapanya melalui cara yang sama. Cuma hak untuk berjumpa anak ditentukan di hujung minggu setiap dua bulan tanpa boleh bermalam.

\section{Kesimpulan dan Cadangan}

Daripada perbincangan di atas, dapat disimpulkan bahawa selagi pihak yang tidak memeluk agama Islam tidak memfailkan petisyen pembubaran perkahwinan di Mahkamah Sivil, selagi itulah pembubaran perkahwinan tersebut dianggap tergantung walaupun pihak yang memeluk agama Islam mendapat pengesahan bahawa perkahwinan tersebut terbubar di Mahkamah Syariah.

Bagi mengelak polemik ini dan juga konflik bidang kuasa antara Mahkamah Sivil dan Mahkamah Syariah, adalah dicadangkan agar seksyen 51 Akta 164 dipinda bagi memastikan keadilan terlaksana ke atas kedua-dua pihak ibu bapa sama ada yang menukar agama dan juga bagi yang tidak menukar agamanya.

Manakala cadangan pindaan ke atas seksyen 88AAkta 164 boleh ditangguhkan kerana tidak berperlembagaan dan bercanggah dengan Perkara 12(4). Begitu juga berlaku ketidakseragaman peruntukan dalam mendapat keizinan bagi pemelukan agama Islam bagi kanak-kanak bawah umur dalam enakmen pentadbiran undangundang Islam negeri-negeri. Ada yang memperuntukkan persetujuan ibu atau bapa/penjaga, dan ada juga ibu dan bapa/penjaga.

Penyelesaian kepada pertikaian ini bukanlah satu perkara yang mudah. Ia memerlukan kerjasama semua pihak terutama ibu bapa/penjaga dan peruntukan undang-undang yang melihat kepada kebajikan kanak-kanak tersebut.

Seharusnya juga, hakim Mahkamah Syariah hendaklah bersidang bersama hakim Mahkamah Sivil apabila kes mengenai undang-undang Islam dibangkitkan dalam Mahkamah Sivil. Hakim Mahkamah Syariah boleh dipinjamkan ke Mahkamah Sivil apabila ada keperluan. Sedikit pindaan perlu dibuat kepada Perkara 122B, Perkara123 Perlembagaan Persekutuan dan Akta Mahkamah Kehakiman 1964.

Pertikaian hak dalam menentukan agama dan hak penjagaan kanak-kanak juga boleh diselesaikan melalui satu tribunal yang mengambil pendekatan mediasi. Panel yang dilantik mestilah terdiri daripada pihak yang beragama Islam dan 
bukan Islam. Ini dapat mengurangkan konflik antara pihak yang terlibat malah dapat mengelakkan konflik bidang kuasa antara Mahkamah Sivil dan Mahkamah Syariah dalam memutuskan tuntutan yang dikemukakan.

\section{Notes}

* Mohamed Azam Mohamed Adil Deputy CEO, International Institute of Advanced Islamic Studies (IAIS) Malaysia, Jalan Elmu off Jalan Universiti, 59100 Kuala Lumpur/Associate Professor, Academy of Contemporary Islamic Studies (ACIS), Universiti Teknologi MARA Selangor, 40450 Shah Alam, Selangor (mazamadil@iais.org.my/mazamadil@hotmail.com).

** Rafeah Saidon Senior Lecturer, Academy of Contemporary Islamic Studies (ACIS), Universiti Teknologi MARA Selangor, 40450 Shah Alam, Selangor (rafeahsaidon@hotmail.com).

1. Noor Aziah Haji Mohd Awal, 'Section 51 of the Law Reform (Marriage and Divorce) Act 1976: An Overview,' Jurnal Undang-undang IKIM 3, no. 2 (1999): 133.

2. Ahmad Ibrahim, 'The Need to Amend Section 51, Law Reform (Marriage and Divorce) Act 1976,' MLJ(1990): lviii-lix; Ahmad Ibrahim, 'Effect of Conversion on Marriage - Section 51 of the Law Reform (Marriage and Divorce) Act, 1976,' dalam The Administration of Islamic Law in Malaysia, disunting. Ahmad Ibrahim (Kuala Lumpur: Institut Kefahaman Islam Malaysia, 2000), 215-6.

3. Najibah Mohd Zain, 'Harmonising the Conflicts in Family Related Disputes Upon Conversion of One Spouse to the Other Religion,' International Seminar on Syariah and Common Law 2006, Hotel Seri Kembangan, Selangor, 20-21 September 2006, 2.

4. Ahmad Ibrahim, 'The Need to Amend Section 51,' lviii-lix; Ahmad Ibrahim, 'Effect of Conversion,' 215-6; Mohamed Azam Mohamed Adil, 'Seksyen 51 Akta Membaharui Undang-undang (Perkahwinan dan Perceraian) 1976: Kesan dan Implikasinya Terhadap Pemeluk Agama Islam,' Jurnal Tasawwur Islam 4 (2000): 67; Najibah, 'Harmonising the Conflicts,' 2; Noor Aziah, 'Section 51 of the Law Reform,' 133.

5. Civil Appeal No. A-02-1826-08/2013.

6. [1990] 1 MLJ 86.

7. Ahmad Ibrahim, 'Effect of Conversion on Marriage,' 216-217.

8. [1990] 2 MLJ 307.

9. Ahmad Ibrahim, 'Effect of Conversion on Marriage', 216; lihat Ahmad Ibrahim, 'The Need to Amend Section 51,' lvii.

10. [1984] 1 MLJ 141.

11. Noor Aziah, 'Section 51 Law Reform,' 131- 2; Noor Aziah Haji Mohd Awal, 'A Child's Right to Religion in Malaysia: An Overview,' Jurnal Undang-Undang IKIM 9, no. 1 (2005): 299-309.

12. [1991] 3 MLJ 117.

13. Noor Aziah, 'Section 51 Law Reform,' 299-309.

14. Mohamed Azam Mohamed Adil and Ahmad Badri Abdullah, 'Penukaran Agama 
Kanak-kanak: Isu dan Cadangan,' IAIS Malaysia Policy Issues Papers 3, (2016): 6-7.

15. Terdapat beberapa hadith diriwayatkan mengenai hal ini oleh Al-Bayhaqi, al-Sunān al-Kubrā v. 2 (Beirut: Dār al-Kutub al-'Ilmiyyah, 2003), 333-8. AlBayhaqi menambah bahawa 'Abd Allah b 'Umar al-Khattab masih kecil ketika beliau memeluk Islam iaitu ketika bapanya memeluk Islam, begitu juga dengan 'Abd Allah b. Abbas memeluk Islam ketikamana ibunya memeluk Islam.

16. Wizarāt al-Awqaf, al-Muwsū 'ah al-Fiqhiyyah $3^{\text {rd }}$ ed, vol. 6/27 (Kuwait: Darul Fikr, 1970).

17. Sahih al-Muslim, no. hadith. 4809.

18. Sebagai contoh, lihat Enakmen Pentadbiran Undang-Undang Islam Selangor 1952.

19. Mohamed Azam and Ahmad Badri, 'Penukaran Agama Kanak-kanak,' 3-5.

20. Ibid.

21. Mohamed Azam Mohamed Adil dan Rafeah Saidon, Penentuan Agama dan Hak Penjagaan Kanak-Kanak Menurut Undang-undang Islam (Putrajaya: Jabatan Kemajuan Islam Malaysia, 2014), 21-3.

22. Teoh Eng Huat lwn Kadhi Pasir Mas \& Anor [1990] 2 MLJ 300.

23. Mohamed Azam dan Rafeah Saidon, Penentuan Agama, 21-3.

24. Subashini a/p Rajasingam lwn Saravanan a/l Thangthoray \& Anor [2008] 2 CLJ 1.

25. Mohamed Azam dan Rafeah Saidon, Penentuan Agama, 4.

26. 'Kerajaan tangguh pembentangan Akta 164,' Diperolehi di: http://www. Malaysiakini.com. (Dibaca pada 6 April 2017).

27. Najibah, 'Harmonising the Conflicts,' 2.

28. Mohamed Azam dan Rafeah Saidon, Penentuan Agama, 5-6.

29. Ibid.

30. Seksyen 80(2), Enakmen Undang-undang Keluarga Islam Selangor 2003.

31. Seksyen 87(1), Enakmen Undang-undang Keluarga Islam Selangor 2003.

32. Sayid Sabiq, Fiqh Sunnah, vol. 8, penterjemah. Mohd Talib (Kuala Lumpur: Victory Agency, 1990), 168.

33. Abdul Rahman al-Jaziri, Kitabul Figh ala al-Mazhab al-Arba'ah, vol. 4 (Beirut: Darul Fikr, 1986), 597.

34. Sayid Sabiq, Fiqh Sunnah, 168; Muhamad Arifin, 'Hak Penjagaan Anak (Hadhanah) Mengikut Undang-undang Keluarga Islam,' dalam Manual Undangundang Keluarga Islam, ed. Abdul Monir Yaacob dan Siti Shamsiah Md. Supi (Kuala Lumpur: Institut Kefahaman Islam Malaysia, 2006), 142.

35. Al-Jaziri, Kitabul Fiqh, 596-8; al-Marghinani, The Hedaya Commentary on the Islamic Laws, vol. 1, penterjemah. Charles Hamilton (London: Kitab Bhavan, 1985), 389.

36. Jamal J. Nasir, The Islamic Law of Personal Status, $2^{\text {nd }}$ ed., (London: Grahan \& Trotman, 1990), 180; Jamal J. Nasir, The Status of Woman Under Islamic Law and Under Modern Islamic Legislation (London: Graham \& Trotman, 1990) 128.

37. Normi Abdul Malik, 'Hadhanah Menurut Undang-undang Islam dan Pelaksanaannya di Malaysia,' Law Journal IKIM 8, no. 2 (2004): 52.

38. Najibah, 'Harmonising the Conflicts,' 3. 
39. Zanariah binti Noor, 'Agama dan Akhlak: Satu Analisa Kelayakan Pengasuh dalam Kes Hadhanah,' Journal Syariah 12 (2004): 59-60; Muhamad Arifin, 'Hak Penjagaan Anak,' 142.

40. Nuraisyah Chua Abdullah, Conversion to Islam: Effect on Status of Marriages and Ancillary Reliefs (Petaling Jaya: International Law Book Services, 2004), 43.

41. [2004] 2 MLJ 241.

42. [2003] 5 MLJ 106.

43. Q. al-Baqarah 2:256

44. [2008] 2 CLJ 1, FC.

45. [2015] 3 MLJ 209. 